\title{
Police Efforts in Tackling Theft Crimes
}

\author{
Nur Alam Syaf ${ }^{1}$, Suparno ${ }^{2}$ \\ University of Borobudur ${ }^{1,2}$ \\ \{alamsyahn990@gmail.com¹, suparno@borobudur.ac.id² $\}$
}

\begin{abstract}
Crime often occurs with various backgrounds, which are frequently encountered, for example, due to economic factors. A person can act recklessly to steal for reasons that there is no cost to life, bullying, or even stem from bad habits or diseases such as gambling, drunkenness, and prostitution, even narcotics. The method of approach in this study uses an empirical juridical legal system. Legal Research on the application or implementation of normative legal provisions in action on any particular legal event in the community.
\end{abstract}

Keywords: Police; Countermeasures; Theft; Criminal Acts

\section{Introduction}

Indonesian Constitution listed in the 1945 Constitution in Article 1 paragraph 3 states that "Indonesia is a State of law" in addition to the General Explanation of the Opening of the 1945 Constitution on the State System of Government explained that: "Indonesia is a State based on the law is not based on mere power". It means that in the State of the Republic of Indonesia, everything and regulation in the state aspect are regulated based on the Law. And the purpose of the Law is to control people's living systems and create security, welfare and social justice. Simultaneously, the criminal's objective is for revenge or to satisfy the party that grudges both the community itself and the party that was harmed or became the victim of a crime. There is the oldest goal of funding.

The criminal objectives seen now are: prison, either for perpetrators or even those who have the potential to commit crimes, protection to the community from evil deeds, improvement to criminals, to foster lawbreakers to have criminals out of prison or the completion of the sentence can be accepted by the community again. Although there is already a penalty for the crime perpetrator, it does not reduce a person to commit a criminal act. There is proven by the increasing criminal acts over time.

Crime often occurs with various backgrounds, which are frequently encountered, for example, due to economic factors. A person can act recklessly to steal for reasons that there is no cost to life, bullying, or even stem from bad habits or diseases such as gambling, drunkenness, and prostitution, even narcotics. To fulfil their bad habits with less financial conditions, even bullying makes them commit crimes, especially theft.

Theft crimes can be processed through law enforcement. Theft is a criminal offence directed against a person's property or property. This crime is the type of crime that most often occurs in the middle of people's lives. Although this crime is not a criminal offence classified as a serious crime such as murder, it can cause unrest in the community, especially those who live or live in the neighbourhood where the theft occurred. 
The 1945 Constitution, as a constitutional basis, mandates the principle of every citizen equal in position in Law and government. There is not proven by the imbalance between the protection of the Law between the protection of victims of crime and the perpetrators of crimes because there are still few rights - the rights of victims of crime are regulated in national legislation. All human activities in all aspects of social, political, and economic life can cause corruption.

The Police's task is not only related to the process of law enforcement but also related to measures to prevent criminal acts or criminality. These crime prevention efforts are a decisive step to confront the crimes that have grown in recent times. Crimes that increased from the previous year need to be done crime prevention, especially by the Police, to not happen again for the following year. Also, what steps can be taken by the community to support the prevention.

\section{Methodology}

The method of approach in this study uses an empirical juridical legal system. Empirical juridical Research is legal Research on the application or implementation of normative legal provisions in action on any particular legal event in society. Which in this study illustrates between the laws and regulations with empirical understanding.

This Research is descriptive Research, which is Research that describes or explains and gives data as detailed as possible about the problem of theft in Police XXX. The data obtained from the study results will be analysed using descriptive analysis methods that clearly describe with sentences to answer the obstacles to implementing criminal law settlement.

\section{Result and Discussion}

\subsection{Police Efforts in Law Enforcement of the Crime of Theft}

Theft is a crime that has occurred from time immemorial to the present. The development of the perpetrators of theft crimes is increasingly dangerous, and often the perpetrator injures the victim even has many victims died. Through PERMA No. 2 of 2012, cases with the object of a case worth no more than Rp.2.500.000,00 (two million five hundred thousand rupiahs) are considered as a form of a minor crime. Through this Perma, perpetrators who meet these conditions can not be arrested automatically because they no longer meet the requirements stipulated in Article 21 paragraph (4) kuhap because the perpetrator's threat is only three months in prison or less than five years in prison. Thus, the case cannot be filed for cassation because of the threat of a sentence of less than one year in jail.

Role of police action in handling the crime of theft can be seen that the steps of the Police $\mathrm{Xxx}$ in addressing the crime of robbery in the future is in addition to maintaining the program (Permanent Program) namely Patrol, Chain, startup, Community Policing, Kring Serse, early detection, handling crime scenes that are beaten up. Police, Polwiltabes and Polda / and the title of the case until the disclosure of the matter is also added with the police chief called GRAND STRATEGI, POLRI Which is divided into three stages, namely:

a. Phase I TRUST BUILDING 2005-2010.

b. Phase II PARTNERSHIP 2010-2015 (building partnership).

c. Phase III Strive for Excellent 2015- 2025 Excellent community service 
d. Quick Response (Speed to visit the crime scene, Speed to serve community report, increased patrols in vulnerable areas.

e. Transparency of Investigation through SP2HP (Notice of Investigation Result) must be periodically reported to the reporter, victim, or suspect's family for some instances as Police respond to the public.

f. The police members' recruitment transparency will determine the Police's performance and success in handling the case significantly.

In the jurisdiction of Police, in 2010-2015 partnership stage built a partnership that has also begun to be pioneered with the activities of Community Policing that are vigorously carried out in the ranks of Police; the movement is marked by the establishment of several FKPM (Community Police Communication Forum) in several places, including infrastructure buildings in the form of posts and FKPM halls. The effort is expected xxx police year has been realised so that the community can mainly become Police for himself and the broader consequences of narrowing the perpetrators' movement space. In 2015 - 2025 the strive for excellent stage (Excellent community service) is expected all police services, including theft, the incidence rate is minimal, and the number of cases is very high.

From the program can be described that in carrying out its primary duties and functions under Law no. 2 of 2002, concerning the State Police of the Republic of Indonesia, to maintain the security and public order of the Police to provide protection and protection and service to the community, through law enforcement activities against perpetrators who violate applicable laws, especially criminal law regulations. In its implementation, the National Police is authorised by Law as the executor of criminal justice's investigative function.

For the disclosure of cases conducted through the process of investigative activities conducted professionally, proportionally, effectively and efficiently, the mobiliser, regulator and controller of investigations in the exposure of criminal cases are carried out by the Kanit and Kasat Reskrim for all units based on managerial capabilities and technical and tactical capabilities of inquiry. In carrying out investigative activities for the disclosure of cases, investigators/investigators assistants are given legal authority that is coercive and can even deprive a person's human rights in the interests of the Law to find suspected criminal perpetrators and prove it based on valid evidence (article 184 KUHAP). With the legal authority owned by the investigators/investigators assistants and or investigators, encourage a person or a group of people who are in his interest.

Establishing mutually beneficial relationships with investigators, auxiliary investigators regardless of the prevailing laws. Limitations of Reskrim resources and inadequate levels of member welfare, resulting in irregularities in the implementation of investigation activities. And in the activities of collecting data, information, and information related to a criminal case, either about the existence of evidence or the actions of someone who is suspected as a criminal, members still often use threats of violence or with violence so that the case can be revealed immediately. To increase the disclosure of issues and eliminate food sprinklers that occur, the Head of the Unit and the Head of the unit have a very strategic role, where the Head of the company that directly oversees the investigators / auxiliary investigators in the team, and Kasat Reskrim as the person in charge of the activities of the Unit Reskrim Function, to achieve the objectives and objectives that have been set by the leadership, in addition to having managerial capabilities and technical and tactical capabilities of investigation, must also be supported by the commitment of all police chiefs in particular and generally the Police in stages.

In the implementation of investigation activities, namely investigation activities, forced effort activities, examination activities, and case resolution activities carried out by the 
Reskrim unit with the managerial application, from the observation results can be the following facts and results:

a) Case Handling Mechanism.

1. Picket Reskrim carried out by a unit when it will be finished carrying out the police report picket submitted to Kasat Reskrim, after Kasat Reskrim studies the Police Report, give a note in the appearance sheet and appoint the Head of a unit which handled the case

2. After being recorded and data by Urbin ops Reskrim, the matter was distributed by the unit's Head for follow-up.

3. Upon receipt of the Police Report from Urbinops, Kanit studied it. By disposition on the take sheet with an 'immediate process' order, it was then handed over to the appointed assistant investigator.

4. If there will be forced efforts in the form of arrest, detention, and suspension of imprisonment, at the discretion of Kasat, Reskrim conducted a title case (the result of the investigation) both at the unit level and the Unity level.

5. When the case is handled in a matter that is in the public spotlight and or complicated, the case's title is carried out by involving the upper unit and the state prosecutor and related agencies.

6. The entire administration of the investigation is signed by Kasat Reskrim, except for a warrant for suspension of detention.

b) Implementation of Investigation Activities.

1. The description of the leading policy in the function unit, especially in improving the disclosure of cases orally or writing, does not exist. At the policy level, the leadership does not reach the investigators/investigators in the unit.

2. There is no priority policy on handling cases from Kasat Reskrim relating to limited budget support

3. To meet the needs of investigative activities, Reskrim Unit, Police Unit and or personal of the investigators / auxiliary investigators often occur irregularities in the implementation of investigation activities

4. The division of case handling to the investigators / auxiliary investigators conducted by the Kanit is not accompanied by instructions and directions that must be achieved in disclosing the case.

5. The ability to disclose cases each month is an average of 1.5 points.

6. Investigators/investigators help each other not know the development of the case handled by other fellow investigators in one unit.

7. The authority of Kasat Reskrim in managing the Reskrim Unit is delegated by the Chief of Police, except in the case of suspension of detention as control of the handling of claims, personnel, and office budgets.

8. Kasat Reskrim signs the investigation's entire administration, so sometimes some letters related to the inquiry run into obstacles, such as subpoenas and others.

9. The Head of the unit's leadership is still formal. The leadership policy rarely reaches the members, does not dare to rebuke the mistakes of members and the issue of investigation and the investigation and responsibility in the disclosure of direct cases by Kasat Reskrim.

10. Analysis and evaluation and administrative activities of the investigation conducted by Kaur Bin Ops Reskrim have been running well, where Kasat and the unit's Head fulfil organisational needs.

c) Cooperation relationship built by Reskrim unit. 
1. The coordination relationship between members of other functional units and Reskrim is quite good, but it has not been seen in the disclosure activities.

2. The relationship between the prosecutor as a public prosecutor and the District court is quite good, and there are still various obstacles in disclosing the case.

3. The Reskrim Unit's relationship with the community, especially those related to criminal cases, is still not maximised. There can be seen one of the complaints of the public against the investigation service.

Before the concept of Community Policing was launched, especially in developed countries, police duties in the maintenance of security and order and law enforcement were carried out conventionally. The Police tend to see themselves solely as holders of authority, and police institutions are seen solely as a state tool. The approach of power and even repressive actions often colour the implementation of police duties and rules. Although the principles of "serve and protect" (to serve and protect) are emphasised, bureaucratic, centralistic, all-in-one/uniform approaches colour police services' presentation. The police force encouraged the Police to put the central government's mandate first and ignore the 'consent' of the local communities served. Also, the Police tend to foster an attitude that presents itself as a formal, exclusive figure of other community members.

Towards the end of the 20th century, a paradigm shift began to mark a change in the human life approach. Universally society tends to become saturated with bureaucratic, official, formal and rigid ways of government institutions. In line with this civilisation's development, various concepts about police approaches were introduced, tested, such as Team Policing, Problem-Oriented Policing, Neighborhood Watch, Citizen Oriented Police Enforcement (COP), Community Oriented Policing and others. All of them are intended to realise a proactive police system that meets the community's expectations and needs so that it is more effective in carrying out its mission as law enforcement and public security maintainers. The approach that emphasises the builder of partnerships with the community and the community's breakdown is ultimately popular with the model name Community Policing (CP). Community policing has been implemented in many countries with various characteristics. The community policing model applied in one country is not the same as that used by another.

These differences are due to various things, among others; social, political and economic conditions and different cultural backgrounds. Because of these differences, the definition of Community Policing is also somewhat different from each other. The concept of Community Policing is not a new concept for the Indonesian nation. The philosophical and practical values of community policing have long developed and are used by the National Police to implement its duties. Siskamswakarsa, with its various activities, is a suitable form of implementation of community policing values. The National Police of the Republic of Indonesia officially implemented the model of Community Policing or "Community Policing", which is a harmonious combination of the concept of community policing applied in several foreign countries with the idea of Bimmas on October 13, 2005, with the issuance of the Decree of the Police Chief with The Number; Skep./737/X/2005. With the Skep publication, the State Police of the Republic of Indonesia implemented a typical Indonesian community policing model with the name or title Community Policing.

In particular, which is a translation of the word "Community" (community) in the context of Community Policing means:

a. Citizens or communities that are in a small area that is the boundaries(geographiccommunity). This community's borders must be done by paying attention to the unique geographical and social characteristics of an environment and especially its effectiveness. 
The area can be RT, RW, village, village, or the form of markets/shopping centres/malls, industrial estates, sports centres/complexes, bus/train stations and others.

b. In an expanded sense, the Community Policing approach can also include a group of people who live in the broader area, such as sub-districts and even districts/cities, as long as they have common interests.

In this sense, the community is empowered so that it is no longer solely an object in the implementation of police functions but as a decisive subject in managing its efforts to create a safe and orderly environment for the peace and safety of life community facilitated by the Police. They act as police officers in a partnership.

Community Policing is basically in line with the values contained in the concept of Siskamswakarsa, which in its development is adapted to the present-day implementation of police functions in today's civil society. Thus the idea is not merely a plagiarising or full adoption of the concept of community policing in general. As a system, there are some elements in Community Policing. However, in practice, the absolute must be pursued two core components of Community Policing, namely partnership and problem-solving. The fundamental component that officers must realise in the implementation of Community Policing is parallel partnerships between the Police and citizens. This similar partnership in its performance is implemented or operationalised in a container called FKPM (Community Police Partnership Forum).

The programs as mentioned above are driven/manned by police personnel with Petty Officer's rank, and therefore the existence and function are known as Babinkamtibmas. In implementing its duties and functions, Babinkamtibmas visited the community in his assigned area while providing counselling on various matters related to security and environmental order development. Different information can be obtained from Babinkamtibmas when making visits and coaching the community. The information is used as input to design the following program of activities. In this case, the police / Babinkamtibmas is limited to the position of extension and coach. The execution of the material complained or fostered by the officer / Babinkamtibmas is entirely dependent on the citizens' commitment.

The formation of Community Policing should be carried out jointly by 3 (three) main pillars of Community Policing, namely:

a. Elements of society in its formation are represented by figures and in its operationalisation by partnership forums (FKPM).

b. Elements of the National Police in its formation are represented by the Police Chief/staff and in its operationalisation by the appointed Police officer.

c. Elements of the local government in its formation are represented by the Camat / staff together with the Lurah / village head/village representative body/village and in its operationalisation by the Lurah / village head.

Community Policing officers are in charge of carrying out the duties and functions of police operational functions related to Community Policing's operationalisation and encourage the proper functioning of Community Policing institutions to solve any problems/disturbances of security and order that occur and or sourced from within the local community. In the framework of the implementation of the main task, Community Policing officers:

a. Perform detection functions;

b. Carrying out the functions of community guidance and counselling;

c. Carrying out general police duties;

d. Carrying out the functions of criminal Reserse on a limited basis;

e. Report any implementation of his duties, both written and oral, to the Police Chief. 
f. Take proportionate police action in the event of an act against the Law deemed necessary, in coordination with the police officer interested/authorised to take over the handling.

g. Resolving minor matters/disputes between citizens based on mutual agreement between the parties to the conflict and, when necessary, with FKPM

h. Take regulatory measures if necessary as a follow-up to the FKPM agreement in maintaining environmental security. FKPM is a community organisation that is independent, independent, and in its activities free from any party's interference. However, its formation is carried out based on a joint agreement between the police chief, subdistrict head/village head / Lurah and community leaders / local community leaders.

FKPM can be referred to by other names and terms or by specific regional languages based on a local community agreement. FKPM is in charge of carrying out activities related to the operationalisation of Community Policing and encouraging the proper functioning of Community Policing institutions to solve any problems of security and order disturbances that occur and are sourced from within the lives of local people. To carry out these tasks, FKPM:

a. Collecting data, identifying problems, and studying instruments;

b. Take proportionate measures in the framework of the implementation of the functions of the general Police;

c. Discussing the social difficulties of Public Order and Security aspects in their region

d. Exploring and establishing an annual/ quarterly work program

e. Follow up on the work program;

f. Continuously monitor the implementation of citizen activities from aspects of an order, including security and public order disturbances;

g. Accommodate citizen complaints about social issues.

Enforcement or prevention efforts in criminal acts/crimes of theft of the police work under the Law's duties, functions, and authorities - Law governing the Police. Law - Law of the Police of the Republic of Indonesia Number 2 the Year 2002 in Articles 13 and 14, explained that the primary duties of the Police are (a) Keeping the Law, (b) Enforcing the Law, (c) Provide protection and protection to the community.

The public should also participate, at least reporting anything related to activities related to theft. To facilitate the community's participation, the Police must actively encourage messages and invitations to report to the Police when viewing theft activities. Preventive legal efforts must take precedence because if the Police and the community have synergised and cooperated well, it is likely that the crime of theft can be addressed. After all, the Police's supervision comes from the Police also comes from the community itself to protect the environment.

\subsection{Constraints Faced by the Police Regarding Law Enforcement on the Crime of Theft}

The word law enforcement has the connotation of enforcing, implementing the Law provisions that apply in society. In the broader context of law enforcement, the continuity of the realisation of abstract concepts becomes a reality. In the process, the Law is not independent, meaning other factors are closely related to the law enforcement process that must be included, namely the community and law enforcement officials. Therefore, the Law is not more just ideas or concepts that reflect the so-called justice, order, and legal certainty that is poured in the form of legislation to achieve a specific goal. However, it does not mean that the prevailing laws are defined as complete and perfect but rather a framework that still requires improvement. The process of realising the purpose of the Law is determined by law enforcement officials' professionalism, which includes the ability and skills both in describing 
the rules and in their application. Law enforcement is the implementation of legislation, but some factors hinder, among others.

a. The legal factor itself.

b. Law enforcement factors, namely the parties that form and who apply the Law.

c. Factors of facilities or facilities that support law enforcement.

d. Community factors, i.e. the environment in which the Law applies or is

e. Cultural factors, namely as the result of work, copyright and taste based on a human initiative in life's association.

These five factors are interrelated with each other as the essence of law enforcement and a benchmark for law enforcement's effectiveness, which is explained. Based on the results of the study, factors inhibiting the enforcement of criminal Law against criminal acts of theft in the jurisdiction of The Police As follows:

a) Statutory Factors (Legal Substance)

The practice of enforcing law enforcement in the field is often a conflict between legal certainty and justice. The conception of justice is an abstract formulation, while legal certainty is a normatively determined procedure. Therefore an action or policy or policy that is not entirely based on Law is justified as long as the policy or activity is not contrary to law. In essence, the Law's implementation includes law enforcement and peace maintenance. The Law's performance is a process of harmony between values and rules and authentic behaviour patterns to achieve peace. Thus, it does not mean that every social problem can only be solved by written Law because there can not be legislation that regulates all human behaviour, whose content is clear to every citizen that is regulated and harmonious between the provisions to apply the rules with supportive behaviour.

b) Law Enforcement Factors

One of the keys to success in law enforcement is its own law enforcement's mentality or personality. In terms of law enforcement and law enforcement implementation that the enforcement of justice without truth is depravity. The enforcement of truth without honesty is hypocrisy. In the framework of law enforcement by every law enforcement agency, justice and truth must be declared, must be felt and seen and must be actualised. Law enforcement has always seemed to be a select cut if the small community that commits a criminal act is directly enforced, this is different when a criminal is a rich person or a person who has a position, law enforcement officials seem not to know, the process of law enforcement is so long. It is also worth noting that judges, as law enforcement officials, also have professionalism in carrying out their duties. The judge decides a case must be careful, thorough. The judge can also use the theory of proof based on the belief on logical grounds, namely settling a claim based on the judge's opinion to some extent, meaning that the conviction must be accompanied by a conclusion based on specific evidentiary rules, which is based on a free proof system because the judge is free to mention the reasons for his conviction. So it can be seen that law enforcement factors that can hinder law enforcement against perpetrators of criminal theft are the professionalism of law enforcement officials ranging from the Police to the courts, according to their respective duties and responsibilities in the integrated criminal justice system.

c) Facilities and Infrastructure Factors

Tool inadequate transportation and still many roads are damaged, and the lack of lighting lights on the road, especially the street is quiet or far from the crowds so that it becomes the cause of the hamper of the Police to reach areas prone to sedition and pursuit and the limited number of police personnel and vehicles that exist compared to the number of people who must be supervised. 
d) Community Factors

Kesadaran community law is still lacking, and the community is still less active to respond to the Police's call to conduct an environmental safety system. Police are in desperate need of public support and awareness.

\section{Conclusion}

The public should also participate, at least reporting anything related to activities related to theft. To facilitate the community's participation, the Police must actively encourage messages and invitations to report to the Police when viewing theft activities. This preventive legal effort should take precedence because if the Police and the community have synergised and cooperated well, it is likely that the crime of theft can be addressed. After all, this crime's supervision comes from the Police and comes from the community itself to protect its environment.

Factors Inhibiting the enforcement of criminal law against perpetrators of criminal theft are still the factor of law enforcement. It is still the lack of police officers, lack of operational funds, and lack of facilities and infrastructure to carry out their duties as police officers with, per their duties and responsibilities. Also, the public factor is still lacking legal awareness.

\section{References}

[1] Anwar, N. S. (2019). Analisis Transaksi Digital Cryptocurrency Sebagai Investasi Global Dalam Perspektif Hukum Islam (Studi Kasus Dinar Dirham di Makassar).

[2] Gordon, J. M. (1998). Business Law: An Introduction. Business Law: An Introductionby TheBusinessProfessor.Com, 501(c), 428-431.

[3] Santiago, F. (2016). Bunga Rampai Catatan Hukum. Perpustakaan Nasional RI. Katalog Dalam Terbitan.

[4] Supriyanto, Eko Eddya. 2020. Eksistensi Nilai-Nilai Pancasila Dalam Kebijakan Ekonomi Indonesia. 1st ed. Malang: Literasi Nusantara.

[5] Supriyanto, E. E. (2021). Strategi Penerapan Kebijakan Sovereign Wealth Funds (SWFs) di Indonesia: Studi Literatur dan Studi Komparatif Oman. Jurnal Inovasi Ilmu Sosial Dan Politik (JISoP), 3(1), 10-21. https://doi.org/10.33474/jisop.v3i1.6959

[6] Nababan, K. N. N. (2019). Tinjauan Legalitas Transaksi Bitcoin di Indonesia. JuristDiction, 2(5), 1745-1764. 